\title{
Participatory Black Scurf Disease Management on Potato in Nepal
}

\author{
Buddhi P. Sharma ${ }^{1}$ and Ram B. KC ${ }^{2}$ \\ ${ }^{1}$ Senior Scientist, National Potato Research Programme, NARC, Khumaltar \\ <bpsharma@narc.gov.np> \\ ${ }^{2}$ Senior Scientist, Regional Agricultural Research Station, NRC, Nepalganj
}

\begin{abstract}
A farmer's participatory field experiment was accomplished during three consecutive years (2003-2005) for the sustainable management of black scurf disease of potato at Mainapokhar, Bardiya, Nepal. A heavily infested field with Rhizoctonia solani was selected prior to experimentation. Experiment was laid out in randomized complete block design with three replications. The efficacy of two concentrations ( $2 \%$ and $3 \%)$ of boric acid and $0.15 \%$ of Thiophanate Methyl were tested for disease control through seed treatment. An antagonistic fungus Trichoderma harzianum was used as seed and soil treatment. As per treatment plan some plots were sterilized with formaldehyde $1 \%$ prior to planting. The plots having healthy seed (pre-basic seed) planted in sterilized plots showed minimum disease (6.8\%) followed by $3 \%$ boric acid treated seed planted in sterilized plots $(10.8 \%)$ and $2 \%$ boric acid without soil sterilization (13.1\%) and seed and soil treated plot with T. harzianum (17.1\%). Farmers did not accept treatments connected with soil sterilization by Formalin. After analyzing the overall results of three years experiment farmers choose seed treatment with $2 \%$ boric acid prior to planting and identified application of Trichoderma harzianum for black scurf management as second option.
\end{abstract}

Key words: Boric acid, fungicides, potato, Rhizoctonia solani, Trichoderma harzianum

\section{INTRODUCTION}

Potato (Solanum tuberosum) is one of the important food crops after rice, wheat and maize which occupy total area of 1,50,864 hectares with the productivity of $13.09 \mathrm{t} / \mathrm{ha}$ (ABPSD 2006). Present productivity of potato in Nepal seems to be very low as compared to European countries (40-45 t/ha). Diseases are one of the yield reducing factors, which causes low yield of potato. Black scurf caused by Rhizoctonia solani is one of the most important diseases of potato. Black scurf disease symptoms can be found on all underground parts of the plant at different times during the growing season. Disease is pronounced when black sclerotia cover the tuber surface. Under minimum disease severity it just lower down the market price but may not reduce the yield. Under severe conditions, when sclerotia cover more than $50 \%$ area hinders germination of tubers, if get germinated there will be poor plant growth and leads to low yield. Although yield losses associated with this disease are not well documented in Nepal, however, considerable losses due to this disease have been frequently reported.

In Nepal yield losses due to this disease has been estimated ranging 5-60 percent depending on the prevailing weather during the crop period and crop rotation followed. Mid western region particularly Mainapokhar Bardiya is one of the black scurf affected areas, where highest yield losses observed in 2003. Some recommendations have been made for disease control through seed tuber 
treatment with Sodium hypo-chloride $(\mathrm{NaOCl})$. The seed treatment with mixture of Acetic acid $1 \%$ + Zinc sulphate $0.05 \%$ solution for 15 min dip gave $100 \%$ kill of sclerotia (Dutta and Gupta 1982, NPRP 1994).

The fungus survives from season to season primarily as black structures called sclerotia, which are present in soil and on potato seed tubers. After harvest of crop, sclerotia that can be seen on potato seed tubers do no wash off with water. The fungus maintained its life cycle and transmitted by sclerotia on the tubers and within the soil or plant residues. With optimal temperature $\left(18^{\circ} \mathrm{C}\right)$ and soil moisture, the sclerotia germinate and penetrate stems, roots and stolons. Development of sclerotia on tubers is pronounced in poorly drained soils.

The hyphae of Rhizoctonia, attacks developing sprouts, when the soil is cool $\left(50-59^{\circ} \mathrm{F}\right)$ and moist. Symptoms on developing sprouts appear as reddish-brown, discolored areas, and the growing point of severely infected sprouts is often killed (DPP 2000). It was observed that the differences in the incidence of stem canker, stolon canker and black scurf were dominated by the effect of inoculums on seed tubers at planting (Simons and Gilligan 1997).

It was also suggested in the previous report that, tuber treatment of either 2 min dip in $2 \%$ formaldehyde, spray with Peneyethorn, Iprodione or a spore suspension of 106 spores $/ \mathrm{ml}$ Verticillium biguttatum were found most effective if planted in fumigated soil with $500 \mathrm{~L} / \mathrm{ha}$ Metham (Wicks et al 1996) but they have not described effects on environment.

Despite of these recommendations made by the different researchers, almost none of the farmers of Nepal applied these chemicals against this disease because either of low severity of disease in the past or high cost of treatment. Mainapokhar is one of the main potato seed production centers in the mid western development region of the country, where potato being grown continuously for more than a decade. Keeping these points in view farmer's participatory research was under taken at Mainapokhar, for empowering farmers to identify low cost, environment friendly and sustainable technology for black scurf management in collaboration with Regional Agriculture Research Station Nepalganj.

\section{MATERIALS AND METHODS}

A heavily infested field with Rhizoctonia solani was selected prior to experimentation. Treatments were fixed on consultation with participant farmers. Experiment was laid out in randomized complete block design with seven treatments and three replications. Black scurf infected farmers' own potato variety 'Cardinal' was used in the field experiment. Experiment was planted on second week of November in all the experimental years (2003- 2005). Plot size was 2.4- $\times 3.0-\mathrm{m}$. Sprouted seed tubers were planted in $25-\times 60-\mathrm{cm}$ spacing at a normal depth. Recommended dose of Manures (10 t/ha) and fertilizers 150:100:60 kg N, $\mathrm{P}_{2} \mathrm{O}_{5}$ and $\mathrm{K}_{2} \mathrm{O} \mathrm{Kg} / \mathrm{ha}$ respectively were applied. Nitrogen was applied as three split doses. Half amount of Nitrogen, during planting as basal and remaining half was applied during two intercultural operations as split doses. As per the treatments soil was sterilized with Formaldehyde $1.0 \%$ ai concentration through commercial Formalin 39\%. Trichoderma in the form of NIPROT was applied as seed and soil treatment and drenching after germination. As per manufacture's instructions Trichoderma was multiplied in well-decomposed FYM @ $10 \mathrm{~g}$ NIPROT/kg FYM. Commercial brand of Trichoderma 'NIPROT' was well mixed in FYM and kept for 10 days under polyethylene cover to maintain the conducive temperature. Seeds were treated with boric acid of two concentrations ( $2 \%$ and $3 \%)$ prior to panting.

Crop was harvested at 105-110 days after planting. Total yield per plot was recorded. Finally, black scurf severity was recorded on percentage comparing the corresponding pictorial severity scale developed (key for black scurf scoring). Black scurf severity index was computed as reported by Tanil et al 1982. 
Disease severity index $=\frac{\sum(\mathrm{n} \times \mathrm{r}) \times 100}{5 \times \mathrm{N}}$

Where, $\mathrm{n}=$ number of samples in each rating, $\mathrm{r}=$ each rating number, $5=$ highest rating, $\mathrm{N}=$ Total number of samples examined.

On completion of two-season experiment, a village level field workshop was organized involving 20 farmers, two extension staff of concern district. Farmers experience on disease symptoms, experimental procedures and research outputs were shared with other potato seed producing farmers.

In vitro efficacy test of antagonist (T. harzianum) against $R$. solani

Trichoderma harzianum was isolated from the commercial product "NIPROT" manufactured by Bio-Control Research Laboratories, Bangalore and cultured on Potato Dextrose Agar (PDA). Causal pathogen, Rhizoctonia solani was also isolated from infected tubers collected from experimental plot and cultured on PDA medium.

For competitive fungal growth studies $10 \mathrm{~mm}$ size culture disk was inoculated onto the freshly made PDA. Trichoderma culture was placed in the center and $R$. solani culture was placed four sides around the antagonistic fungus. Five such inoculated plates were incubated for 7 days at $22^{\circ} \mathrm{C}$ for their colony development.

\section{RESULTS AND DISCUSSION}

\section{Disease index}

There were significant differences in the disease index observed due to the treatments. The plots having healthy seed (PBS) planted in sterilized plots showed minimum disease index by $6.8 \%$ followed by $3 \%$ boric acid treated seed planted in sterilized plots (10.8\%) and in seed and soil treated with $T$. harzianum (17.1\%). Seed treatment with Thiophanate methyl could not found effective in controlling the black scurf under field conditions (Table 1).

Black scurf disease severity in 2003 was $27 \%$ whereas in 2004 severity reached up to $29 \%$. Disease severity in 2004 was two percent higher than the previous experimental year. The mean disease index over the three experimental years is presented in Figure 1. Disease severity over the experimental years was significantly low as compared to adjoining farmer's field where Cardinal variety was grown. The reason behind it could be the timely irrigation and shallow planting which enhanced the early germination and reduced the infection.

Regarding with the efficacy of fungicides tested against black scurf (Rhizoctonia solani ) in other countries, Fludioxonil (Maxim) consistently provided superior protection (Bains et al 2002). Boric acid (17\% ai Boron) a potential alternative after Benlate was tested against Eutypa lata of grapevines. Five \% boric acid $(18.75 \mathrm{mg} / \mathrm{ml}$ water) significantly reduced the Rhizoctonia disease in vitro and in field trials (Rolshausen and Gubler 2005).

Table 1. Black scurf disease index on potato tuber at harvest under field conditions

\begin{tabular}{|c|c|c|c|c|c|}
\hline \multirow[t]{2}{*}{ SN } & \multirow[t]{2}{*}{ TREATMENT } & \multicolumn{4}{|c|}{ DISEASE INDEX } \\
\hline & & $2003 / 04$ & $2004 / 05$ & $2005 / 06$ & MEAN \\
\hline T1 & SEED AND SOIL TREATMENT WITH T. HARZIANUM & 17.7 & 18.7 & 15.1 & 17.1 \\
\hline $\mathrm{T} 2$ & BORIC ACID (3\%) TREATED SEED IN STERILIZED SOIL & 14.7 & 7.6 & 10.0 & 10.8 \\
\hline $\mathrm{T} 3$ & BORIC ACID TREATED (2\%) SEED IN INFECTED SOIL & 18.3 & 8.4 & 12.6 & 13.1 \\
\hline $\mathrm{T} 4$ & INFECTED SEED IN STERILIZED SOIL & 24.0 & 22.2 & 17.0 & 21.1 \\
\hline T5 & $\begin{array}{l}\text { TREATED SEED WITH ROKO FUNGICIDE IN } \\
\text { INFECTED SOIL }\end{array}$ & 25.0 & 28.0 & 15.8 & 22.9 \\
\hline T6 & HEALTHY SEED IN STERILIZED SOIL & 9.7 & 3.1 & 7.6 & 6.8 \\
\hline $\mathrm{T} 7$ & $\begin{array}{l}\text { INFECTED SEED IN INFECTED SOIL (FARMER'S } \\
\text { PRACTICE) }\end{array}$ & 27.0 & 29.3 & 18.7 & 25.0 \\
\hline & F-TEST & $* *$ & $* *$ & $*$ & \\
\hline & $\mathrm{CV}, \%$ & 13.4 & 22.2 & 10.4 & \\
\hline & LSD 0.05 & 4.6 & 2.4 & 2.05 & \\
\hline
\end{tabular}


There was no significant differences between the disease control in the plots of $3 \%$ boric acid treated seed and of boric acid $2 \%$ concentration, in the first two consecutive experimental years, where as in third year disease index was found significantly low in boric acid 3\% treated plots (Table 1). Despite of low mean disease index of three years due to seed treatment of boric acid 3\% planted in sterilized soil (10.8) farmers choose seed treatment with boric acid 2\% planted in unsterilised soil simply because of low cost on seed treatment and no need of formaldehyde for soil sterilization (Figure 1). Over all results of three years showed that planting healthy seed in sterilized soil was the best option for black scurf management. On the other hand, farmers hesitate to use chemicals like formaldehyde for soil sterilization, which increases the cost of production. Evaluating the pros and cons of all treatments farmers choose seed treatment with boric acid 2 percent. Application of antagonistic fungus (T. harzianum) to tuber treatment, soil treatment and drenching was found comparable with infected seeds planted in sterilized soil with formaldehyde (Table 1). Overall black scurf disease severity in the check plot was highest during 2004 crop season, whereas in 2005 disease severity was minimum. The reason behind it could be the cumulative rainfall during the tuber maturity period was high as compared to other years. In 2005/06, there was no rainfall in whole potato crop season (Figure 3).

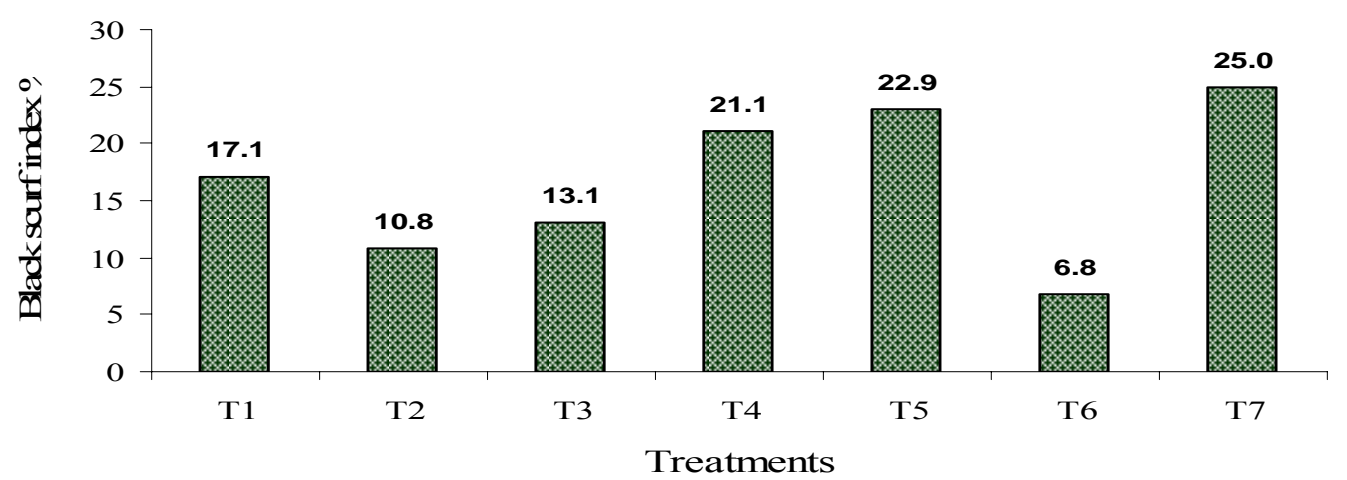

Figure 1. Mean effects of treatments over the three years on black scurf disease index.

In-vitro studies also showed that growth of $R$. solani was completely covered and suppressed by the profuse growth of $T$. harzianum, which was isolated from "NIPROT" under the temperatures of $22^{\circ} \mathrm{C}$. In-vitro results showed that use of Trichoderma harzianum can check the $R$. solani significantly if the population of antagonist sufficiently exists in the soils.

Results of similar studies have been reported by Martin and Robert in 2005. They found that out of twenty eight potential bio control organisms tested for efficacy against Rhizoctonia solani on potato in series of greenhouse trial, one combination of bio-control organisms Bacillus subtilis and Trichoderma virens demonstrated some what better control of stem canker than each organism alone and has been suggested that this approach may provide improved bio-control efficacy. In 2001 Tsror et al had also reported the efficacy of Trichoderma harzianum on pathogenic Rhizoctonia in reducing the incidence of black scurf on daughter tubers using naturally infested soil and contaminated seed tubers.

\section{Disease control}

Treatments were assessed for impact on black scurf disease control based on the severity disease index as shown in Table 1. On an average disease control was achieved up to $70.9 \%$ where disease free tubers planted in sterilized soil (Table 2). Efficacy of T. harzianum showed effective control ranging 19.0 to $36.4 \%$. Mean disease control was $30.0 \%$ over the three crop seasons (Table 2). Three percent boric acid treated seed plots showed significant control of black scurf $(55.4 \%)$ 
followed by boric acid 2\% (41.7\%). Efficacy of these boric acid concentrations were found comparable regarding with disease control. Soil sterilization with Formaldehyde 1\% had a role of controlling $14.8 \%$. Role of infected seed tubers on developing disease severity was found higher than the Rhizoctonia infested soil.

Soil sterilization with Formalin is common practice in glass house crop cultivation. Formaldehyde at $0.8 \%$ has been used for substrate (soil) sterilization in glasshouse by covering soils for 7 days for the control of soil borne diseases (NPRP 2005). It has been also reported that when formalin is used for soil fumigation, it does not harm to antagonistic fungus Trichoderma. In rhizosphere soil of potato field of CPRI Shimla eighteen pathogenic and non pathogenic fungi had been recovered. When soil was treated with Formalin at $400 \mathrm{ppm}$ there was no effects on none pathogenic fungi like Trichoderma, Penicillium, Aspergillus and Gliocladium whereas Rhizoctonia and Fusarium spp were controlled in the treated plots (Rai 1984)

\begin{tabular}{clcccc}
\multicolumn{2}{c}{ TABLE 2. BLACK SCURF DISEASE CONTROL \% ON POTATO TUBER AT HARVEST UNDER FIELD CONDITIONS } \\
\hline \multicolumn{1}{c}{ Treatment } & \multicolumn{4}{c}{ Disease control, \% } \\
\cline { 3 - 6 } & & $03 / 04$ & $04 / 05$ & $05 / 06$ & MEAN \\
\hline T1 & Seed and Soil treatment with T. harzianum & 34.6 & 36.4 & 19.0 & 30.0 \\
T2 & Boric acid (3\%) treated seed in sterilized soil & 45.7 & 74.2 & 46.2 & 55.4 \\
T3 & Boric acid treated (2\%) seed in infected soil & 32.1 & 71.2 & 21.9 & 41.7 \\
T4 & Infected seed in sterilized soil & 11.1 & 24.2 & 9.0 & 14.8 \\
T5 & Treated seed with ROKO fungicide & 7.4 & 4.5 & 15.2 & 9.1 \\
T6 & Healthy seed in sterilized soil & 64.2 & 89.4 & 59.0 & 70.9 \\
T7 & Infected seed in infected soil (Check) & 0.0 & 0.0 & 0.0 & 0.0 \\
\hline
\end{tabular}

\section{EFFECTS ON YIELD}

Tuber yield from the plot of pre basic seed (PBS) planted in sterilized plot was highest $(29.73 \mathrm{t} / \mathrm{ha})$ followed by seed treatment with boric acid 3\% planted in sterilized plot (27.7 t/ha) and Trichoderma harzianum applied plot $(24.88 \mathrm{t} / \mathrm{ha})$. This yield was comparable with the yield of boric acid $2 \%$ treated plot $(26.04 \mathrm{t} / \mathrm{ha})$. Among the results of three years, yield differences between the two treatments boric acid $2 \%$ and $3 \%$ in the last two experimental years were found at par. Significantly higher tuber yield was produced in $T$. harzianum treated plot $(25.12 \mathrm{t} / \mathrm{ha})$ as compared to farmers practice (Table 3). Results indicate that biological control through $T$. harzianum would be one of the new options for long-term black scurf management under mid western terai conditions of Nepal. When population of $T$. harzianum gets well established in the soil, disease could be controlled significantly in the succeeding years.

Abada in 1994, reported that Trichoderma harzianum caused a great reduction in the infection level of damping off and root rot disease of sugar beet and resulted increased root weight both in pot and in field experiment.

Table 3. Effects of treatment on potato tuber yield (t/ha) under field conditions

\begin{tabular}{|c|c|c|c|c|c|c|}
\hline \multirow[b]{2}{*}{ SN } & \multirow[b]{2}{*}{ Treatment } & \multicolumn{4}{|c|}{ Tuber yield, t/ha } & \multirow{2}{*}{$\begin{array}{c}\text { Farmers } \\
\text { Acceptance } \\
\text { score }(1-5)^{*}\end{array}$} \\
\hline & & $03 / 04$ & $04 / 05$ & $05 / 06$ & Mean & \\
\hline T1 & Seed and Soil treatment with T. harzianum & 27.41 & 25.12 & 22.11 & 24.88 & 2 \\
\hline $\mathrm{T} 2$ & Boric acid (3\%) treated seed in sterilized soil & 30.32 & 28.76 & 24.00 & 27.70 & 4 \\
\hline $\mathrm{T} 3$ & Boric acid treated (2\%) seed in infected soil & 27.08 & 27.66 & 23.38 & 26.04 & 1 \\
\hline $\mathrm{T} 4$ & Infected seed in sterilized soil & 23.80 & 26.50 & 22.08 & 24.13 & 5 \\
\hline T5 & Treated seed with ROKO fungicide & 24.81 & 22.89 & 21.71 & 23.14 & 5 \\
\hline T6 & Healthy seed in sterilized soil & 32.87 & 30.50 & 25.81 & 29.73 & 3 \\
\hline \multirow[t]{4}{*}{$\mathrm{T} 7$} & Infected seed in infected soil (Check) & 23.61 & 22.49 & 21.39 & 22.50 & \\
\hline & F-test & $* *$ & $* *$ & $*$ & & \\
\hline & $\mathrm{CV}, \%$ & 4.54 & 4.47 & 7.15 & & \\
\hline & LSD 0.05 & 1.58 & 2.7 & 2.89 & & \\
\hline
\end{tabular}

* 1= HIGHLY ACCEPTED. 5 = POORLY ACCEPTED. 
Regarding with the tuber yield of three years it was found in decreasing trend. The factors behind it could be fertile soil and better irrigation in the first year. On second and third year experimental plot was changed as per the farmers' crop rotation scheme. In addition, there was no rainfall during the crop period of third year (Figure 3).

\section{FARMER'S ACCEPTANCE}

The participants did not accept sterilization of soil with Formalin in a larger potato growing area. All the treatments connected with soil sterilization were poorly accepted (rejected) even yield was significantly higher (Table 3 ). Tuber yield in seed treatment with $2 \%$ boric acid planted in unsterilized soil was comparable with boric acid 3\% along with soil sterilization. Therefore, farmers selected seed treatment with lower dose of boric acid. Similarly, Application of T. harzianum produced the significantly higher yield than the check plot. These two treatments were considered as effective and easy to use under farmers' conditions.

During the experimental period, black scurf symptoms as whitish-gray mycelia covering over the base of stem near the soil surface, (Figure 2a), aerial tubers on the leaf axils (Figure 2b) and sclerotia were observed on tuber (Figure 2c)

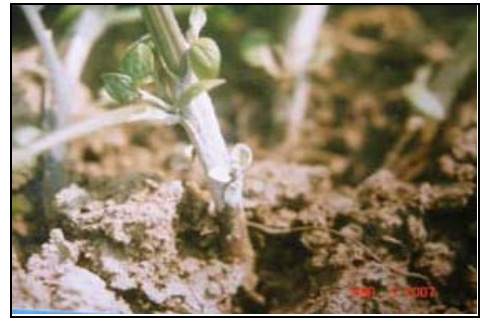

Figure 2a. Sclerotia on tuber

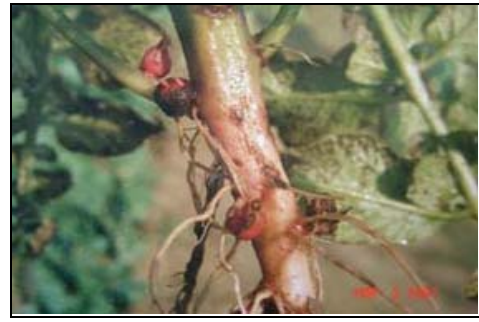

Figure 2b. Aerial tubers on leaf axils Figure 2c. White mycelia on base of stem

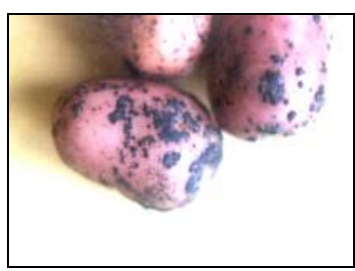
$\longrightarrow$ - Mini Temp

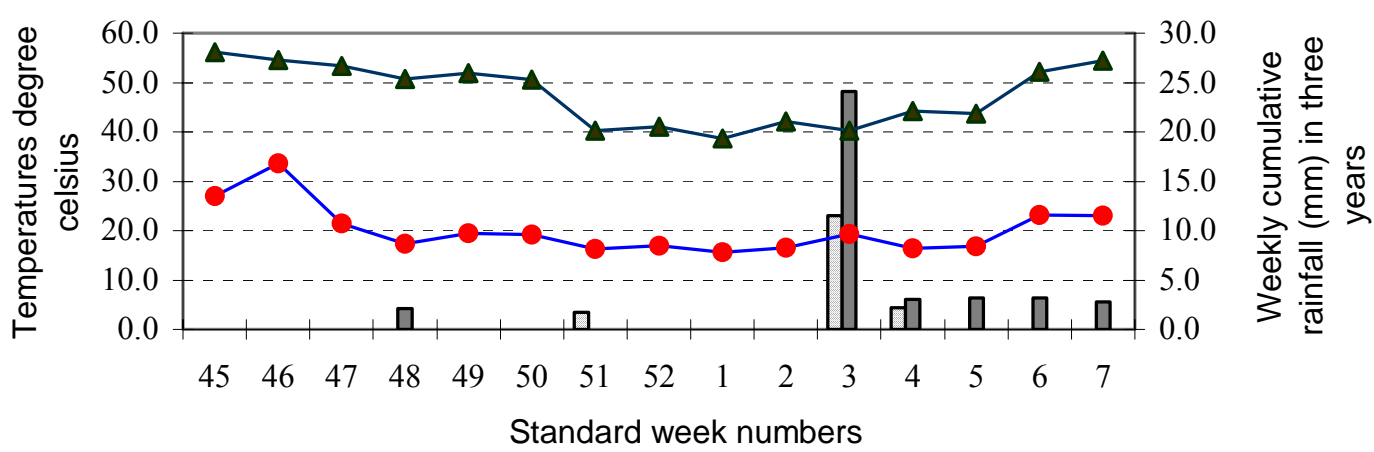

Figure 3. Weekly minimum and maximum temperatures (mean of three years) and weekly cumulative rainfall during the crop period of experimental years (2003-2005).

\section{CONCLUSION}

Potato seed growers empowered for the sustainable management of black scurf of potato and became able to diagnose the disease at different crop growth stages. Farmers selected the option of seed treatment dipping seed tubers in $2 \%$ boric acid concentration for 30 minutes prior to planting to manage the black scurf without soil sterilization with Formalin. However, best results were obtained with healthy seed planted in sterilized soil followed by seed treatment with $3 \%$ boric acid along with 
soil sterilization. Farmers were found reluctant to soil fumigation with formaldehyde because it requires better technical skill otherwise it may be hazardous to user's health. Farmers selected biological control of black scurf through $T$. harzianum as second option. Results obtained from the experiment under naturally infected field conditions of Mainapokhar Bardiya, antagonistic fungus $T$. harzianum could be the environment friendly option for black scurf disease management. Effectiveness of such antagonistic fungus may be increased in the succeeding crops because of its multiplication in the soil.

\section{ACKNOWLEDGEMENT}

Member farmers of 'Kalika Potato Seed Production Group Mainapokhar' who participated in an on-spot black scurf disease management research programme are highly acknowledged for their active participation and collaboration. Authors are thankful to the chairperson of farmers group Mr Kamal Giri, for his effective coordination among the member farmers for conducting this study. Technicians Mr Hari Bahadur KC and Kesab Bahadur Chand are highly acknowledged for experiment management and data collection.

\section{REFERENCES}

Abada KA. 1994. Fungi causing damping off of sugar-beet and their biological control with Trichoderma harzianum. Agriculture, Ecosystem \& Environment 5(3):333-337.

ABPSD. 2006. Statistical information on Nepalese agriculture 2004/05 (2061/62). Agri-Business Promotion and Statistics Division, Ministry of agriculture and cooperatives, Singha Durbar, Kathmandu, Nepal. Pp....

Bains PS, HS Bennypaul, DR Lynch, LM Kawchuk and CA Schaupmeyer. 2002. Rhizoctonia disease of potatoes (Rhizoctonia solani): Fungicidal efficacy and cultivar susceptibility. American Journal of Potato Research 79(2): 99-106.

DPP. 2000. Rhizoctonia disease of potato. In: Vegetable Disease Information Note No. 26. Department of Plant Pathology, North Carolina State University.

Dutta BL and SC Gupta.1982. Efficacy of treatment of tubers in the control of potato black scurf. Potato in developing countries. In: Proceedings of International Seminar, 20-30 Nov. 1978. Pp. 333-338.

MARTIN TB AND PL ROBERT. 2005. EFFICACY OF SEVERAL POTENTIAL BIO-CONTROL ORGANISMS AgAinst RHIZOCTONIA SOLANI ON POTATO. CROP PROTECTION 21:939-950.

NPRP. 1994. The effects of different chemicals for the control of black scurf (Rhizoctonia solani) disease of potato. In: Annual Report 2050/51 (1993/94). National Potato Research Programme,.NARC, Khumaltar, Lalitpur, Nepal. Pp. 36-37.

NPRP. 2005. Glasshouse activities for pre basic seed production. Annual Report 2003/04 (2060/61). National Potato Research Programme, NARC, Khumaltar, Lalitpur, Nepal. Pp. 70.

Rai RP. 1984. Effect of formalin on soil-borne pathogens of potato. Indian Phytopathology 37:694-696.

Rolshausen PE and WD Gubler. 2005. Use of boron for the control of Eutypadiaback of grapevines. Plant Disease 89(7). Pp. 734-738.

Simons SA and CA Gilligan. 1997. Relationship between stem canker, stolon canker and black scurf (Rhizoctonia solani and yield of potato, Solanum tuberosum) under different agronomic conditions. Plant Pathology 46(5). Pp. 651-658.

Tanil AJ, Akai and T Aota. 1982. Chemical control of several diseases transmitted through seed tubers. Potato in developing countries. In: Proceedings of International Seminar, 20-30 Nov. 1978. Pp. 271-278.

Tsror L, R Barak and B Synch. 2001. Biological control of black scurf on potato under organic management. Crop Protection 20: 145-150.

Wicks TJ, B Morgan and B Hall. 1996. Influence of soil fumigation and seed tuber treatment on the control of Rhizoctonia solani on potatoes. Australian Journal of Experimental Agriculture 36(3):339-344. 